\title{
A community-based approach to prevent social exclusion of Somali youth in Finland
}

\author{
Közösségi alapú megközelítéssel a Finnországban élő szomáliai \\ fiatalok társadalmi kirekesztése ellen
}

\section{AHMED MOWLID}

\begin{abstract}
Ahmed Mowlid: MA student; University of Pécs, Faculty of Humanities and Social Sciences, Department of Community and Social Studies; ahmed.mowlid@outlook.com

Mowlid, Ahmed: MA-hallgató; Pécsi Tudományegyetem, Bölcsészet- és Társadalomtudományi Kar, Társadalmi Kapcsolatok Intézete, Közösségi és Szociális Tanulmányok Tanszék; ahmed.mowlid@outlook.com
\end{abstract}

\begin{abstract}
The current study is a brief evaluation of a community-based project called "Gurmad - Save the Youth". The word "Gurmad" comes from the Somali language and it means saving someone. The project was implemented in 2017-2018 in Espoo, Finland. The main aim of the project was to prevent social exclusion and radicalization among immigrant young adults living in the area. Another aim was to create a community-based approach to help solve their social problems. In this study, the Trident approach is utilized to structure the available results of an internal, participatory evaluation. Confirmed strengths of the project could serve as a rationale for the continuation of the programme.
\end{abstract}

Keywords: social exclusion, radicalization, community-based approach, outreach, social integration, evaluation, Trident

\begin{abstract}
Absztrakt
Ez a tanulmány a „,Gurmad-Mentsük meg a fiatalokat!” közösségi program rövid értékeléséröl szól. A „, Gurmad” szó szomáli eredetü, a jelentése: megmentés. Magát a programot 2017-2018ban a finnországi Espoo-ban vezették be. Fö célja a régióban élö bevándorló fiatalok kirekesztésének és radikalizálódásának megakadályozása volt. Egy további célként fogalmazódott meg a fiatalok szociális problémáinak közösségi alapú kezelése. Ebben a tanulmányban a Trident keretei között gondolkodva strukturáljuk a belsö, participációs szemléletü értékelés meglévö eredményeit. Az eredmények, amelyek sikeresen alátámasztották a projekt hasznosságát, megalapozták a projekt folytatását.
\end{abstract}

Kulcsszavak: társadalmi kirekesztés, radikalizáció, közösségi alapú megközelités, megkeresö munka, társadalmi integráció, Trident

\section{Background}

The social project that I am going to evaluate is a community-based project called "Gurmad Save the Youth". The word "Gurmad" comes from the Somali language and it means saving someone. The project was implemented in 2017-2018 in Espoo, Finland. I was the project 
manager for the project. The main aim of the project was to prevent social exclusion and radicalization among immigrant young adults living in the area. Another aim was to create a new kind of community-based approach for these social problems. Community-based approaches can be defined as models of social work practice that seek to work positively and collaboratively with people who have a shared stake in a place, culture, faith, or activity (Miller \& Whitehead, 2015).

According to local press reports and the own observations by the community, several Muslim youths had left for Syria to join ISIS during that time, attracted by extremism. The departure usually took place in secret and its revelation was a shock to both family and friends. Extremism and violent radicalization mean that violence is used, threatened with, and encouraged based on a specific worldview or ideology. Mostly in extreme form, radicalization can lead to terrorist acts. It has been found that hate speech, racism, and violent extremism have increased across Europe, however, violent radicalization is a marginal phenomenon in Finland, and the majority of those who become radicalized never resort to violence (Finnish National Agency for Education, 2018).

Local authorities and community members were very concerned about the situation and the well-being of these young immigrants. It was very sensitive and at the same time a frightening matter. They had to act quickly or otherwise the situation would have gotten out of hand. This was the main reason why this project was launched and funded by STEA (The Funding Centre for Social Welfare and Health Organisations).

Social integration seems to play a vital role in the prevention of extremist movements and violent radicalization. It was noted that marginalized young people without opportunities to make their voices heard are more vulnerable to the promises made by the recruiters than others (Finnish National Agency for Education, 2018). According to statistics, social exclusion is closely tied to immigration and the difficulty of social integration. Almost one-fourth of the excluded youth are immigrants or children of immigrants in Finland. In most cases, those who become socially excluded are young immigrants in search of a job or an education without families as their safety net and live alone (Tuomarla, 2013).

It has been found that family background is another contributing factor to becoming excluded. It can be stated that being socially or financially disadvantaged can be "inherited" as a transgenerational social problem. Out of the currently excluded youth, approximately half have parents who themselves are socially excluded or unemployed. It can be stated that growing up in a home with poor economic and social standing leaves the children without the proper support needed to live in a stable environment, and develop a strong idea of self-worth, develop moral values and determine goals to be pursued. Statistics also show that the children of families with a lower educational background have a higher risk of becoming excluded (Tuomarla, 2013).

One essential theme from the perspective of social exclusion among young immigrants is cultural identity. I live between two different cultures. I was born in Finland and my parents are from Somalia. From my own experience, I can say that living and adapting to two different cultures at the same time can be challenging. In the study of integration, many have studied employment as a major factor or indicator of integration, whereas identity is also an important factor for integration. Studies worldwide show that the mental health issues among immigrants have increased. The ability of immigrants to integrate the cultural identity of their new country is a key factor in their psychological well-being (Pinto, 2014).

The process of radicalization is not straightforward, it can happen slowly or quickly. There is no single factor that can define it. However, some of the identified factors appear to be 
related to social exclusion. The better young people feel that they are equal members of society, they are less influenced by extremist views. The project staff have understood that preventing radicalization in practice is preventing social exclusion.

\section{Evaluation}

I am using the Trident-model to outline the first evaluation results for this project. The Trident evaluation focuses on three pillars: outcome, process, and multiple stakeholder perspectives. These main pillars help the researcher organize their questions and the data obtained into a coherent whole, following a clear logic (Ellis \& Hogard, 2006; B. Erdős \& Vojtek, 2018). The three main questions regarding this evaluation are:

- Has the project achieved its stated outcomes?

- What was the process through which the project was delivered?

- What did people involved in the project think of it?

\section{Has the project met its objectives and intended outcomes?}

As a result of the community-based approach, we met several young people already suffering from social exclusion; or were at risk to be socially excluded. Both social workers employed in the project were young men with a Somali background. This was a great benefit in approaching the young immigrants and this is how during the project we could meet many Somali young men living in the area. It is known that no one left for Syria to join Isis during the project. However, this cannot be counted exclusively as the result of the project because we also did other things to help these young people. This is to say that interim results of an internal evaluation helped us shape the project and connect the young immigrants to existing services. During the project, it was confirmed that with our help and guidance to the appropriate social services several young people got a job, a chance for education, for recreational activities, made new friends, and received information about radicalization. Altogether 40 young people got a job by relying on the network of services brought about by the project.

One of the measurements to analyse the outcomes of the project was a semi-structured interview with four participants of the project (Mowlid, 2018). According to the results, they were satisfied with the activities and the meeting place provided by the project. They also had developmental ideas on how to make these activities more versatile. The results highlighted the importance of leisure time, education, employment, and identity issues. They felt by improving these factors, radicalization can be significantly prevented.

\section{How did the project work, what was the process?}

At the first phase of the project, we opened a low threshold meeting place where young people could spend their free time and have a good time together. We did a lot of outreach work to contact them, and to explore the places where they usually hanged around. We spread the word about our project and our meeting place. We raised awareness in the community, we reached families, mosques, schools, and various people working with immigrant youth. During the twoyear project, I found that young people themselves are the best experts when considering what should be done when preventing social exclusion. Communality is a key factor in the prevention of radicalization, highlighting the importance to include young people, their parents, area mosques, schools, and various people working with immigrant youth. We raised community 
awareness and fostered a sense of belonging to the community, strengthening the own implications of young people.

The second phase of the project was building trust and discussions about the issues. In the beginning, these young people did not have much trust in authorities and because of lack of trust, local authorities did not know how to reach them. So, we became "interpreters" between them, and the trust towards authorities improved what had a positive impact on the community. The trust of young people was gained through common activities. It required presence, listening, and doing things together. For example, we arranged football games on a regular basis. We also arranged seminars for them, for their families, the local authorities, and third sector operators working with young people. In these seminars, we discussed sensitive issues like radicalization. We regularly asked for feedback after the seminars and discussion events. It was one important way to get some inspirations and developmental ideas for the continuation of the project.

In the third phase of the project, we provided guidance and referral to the appropriate social services. We found that there was a high threshold for the young people to find the services they need. We built a network with service providers so that we would be able to guide them with a variety of problems to the competent services, whether it was about unemployment, education possibilities, homelessness, mental health issues, or basic issues of everyday life.

\section{What do all the people involved think of the project?}

Based on the feedback we got from the families, the young people, the funder, and the authorities, the project was seen as having an overall positive impact on the community and people that were involved in the project were largely satisfied and with it. During the project, the four interviewees confirmed that the project had a positive influence on their life, and they felt our meeting place was essential for them. They felt radicalization as an issue did not touch them, but they heard about it. They were concerned about what is going to happen when the project comes to an end.

\section{Ethics}

The role of the researcher in the research is closely connected to the ethics, validity, and reliability of the study. Research ethics in human developmental projects is, in one way, about ensuring the validity of the study. This means for me that the researcher should be careful, transparent, and honest when conducting the research, and prove this to others. As I mentioned before I was the project manager for this project, which is a possible limitation as is usual with internal evaluations. I deliberately did not discuss management issues, an area that I closely identified with.

\section{Conclusions}

There are many projects in Finland and worldwide to promote integration and prevent social exclusion, and therefore radicalization. However, the challenge is the project's nature. It is hard to create functional and productive ways of working if the activity is strongly marked by temporariness and concerns whether this project will continue.

Immigrant youth are constantly facing challenges; therefore, it is important to create functional and permanent services that are relevant to young people's needs. When the project 
came to an end the city of Espoo continued working with these young people using our community-based approach.

In this evaluation, the research data included in the final report of the project (Gurmad, 2018) was used. I used these data as a source to analyse the project results in relation to research objectives. My own observations were confirmed by the final report. However, my observations could have been different if my background had been different - mine is one of the multiple possible perspectives.

I have learnt a lot while doing this project evaluation. The Trident-model gave me new perspectives about the project. Doing this project evaluation was a rewarding experience in terms of learning the Trident-model. I feel that this evaluation deepened my knowledge of programme evaluation. I think as a future social worker that programme evaluation is going to be an essential part of my practice because programme evaluation gives a record of achievement (Ellis, 2018). To sum up: "No innovation without evaluation", what means that if you are innovative and do something interesting, it is great at the time but then it disappears somewhere, and nobody knows what it was, and it is all forgotten. The idea of programme evaluation is that there should be a record of what happened so other people can read it and they can learn from it.

Naturally, there are additional methods that could have made the current evaluation broader and deeper. A practitioner, however, does not always have all the resources to conduct a complex evaluation. As the current study shows, in such cases an internal evaluation can be utilized to fine-tune a project and to help decide about its continuation.

\section{References}

Ellis, R. (2018). The use of programme evaluation in curriculum development. Professionalization of Social Work, University of Pécs, $11^{\text {th }}$ and $12^{\text {th }}$ October, 2018.

Ellis, R. \& Hogard, E. (2006). The Trident: A three-pronged method for evaluating clinical, social and educational innovations. Evaluation, 12(3), 372-383.

Mowlid, A. (2018). The experiences of young immigrants in the Gurmad "Save the Youth" project. (Bachelor's thesis, Laurea University of Applied Sciences). https://www.theseus.fi/bitstream/handle/10024/148576/Ahmed\%20Hussein\%202018.pdf?sequ ence $=1 \&$ isAllowed $=\mathrm{y}$

Gurmad Final Report (2018). Funding Centre for Social Welfare and Health Organisations.

Miller, R. \& Whitehead, C. (2015). Inside out and upside down: Community based approaches to social care prevention in a time of austerity. http://makingitrealindudley.org/wpcontent/uploads/2015/04/Inside_out_and_upside_down_final.pdf.

Finnish National Agency for Education (2018). Prevention of radicalisation in schools and educational institutions. $\quad$ https://www.oph.fi/sites/default/files/documents/prevention-of-violentradicalisation-in-schools-and-educational-institutions.pdf

Tuomarla, E. (2013). Social exclusion of young people in Finland (Bachelor's thesis, University of Metropolia, Helsinki).

https://www.theseus.fi/bitstream/handle/10024/64659/ThesisFinalSubmissionPDF_ErikaTuom arla_Metropolia_UAS.pdf?sequence $=1$

Pinto, A. (2014). Social and cultural integration of Somali immigrants in Finland (Bachelor's thesis, Diakonia University of Applied Science).

https://www.theseus.fi/bitstream/handle/10024/73040/Pinto_Adelia.pdf?sequence=1\&isAllow ed $=\mathrm{y}$ 
Mowlid, A.: Közösségi alapú megközelítéssel a Finnországban élő szomáliai fiatalok...

Erdős, M. \& Vojtek, É. (2018). Programme evaluation for social professionals: Digital textbook. University of Pécs, Faculty of Humanities and Social Sciences, Department of Community and Social Studies \& Social, Innovation and Evaluation Research Centre 